\title{
ENVIRONMENTALLY-ASSISTED CRACKING OF TYPE 316L AUSTENITIC STAINLESS STEEL IN A HYDROGENATED STEAM ENVIRONMENT
}

\author{
1, 2Jaromír JANOUŠEK, ${ }^{3}$ Fabio SCENINI, ${ }^{3}$ Liberato VOLPE, ${ }^{1}$ Anna HOJNÁ, ${ }^{3}$ Mary Grace BURKE \\ ${ }^{1}$ Research Centre Rez, Husinec-Řež, Czech Republic, EU, jas@cvrez.cz \\ 2University of West Bohemia, Faculty of Mechanical Engineering, Department of Material Science \\ and Technology, Pilsen, Czech Republic, EU \\ ${ }^{3}$ The University of Manchester, Material Performance Centre, Manchester, United Kingdom, EU
}

https://doi.org/10.37904/metal.2019.706

\begin{abstract}
A low pressure superheated hydrogen steam system has been used to accelerate the oxidation kinetics while keeping the electrochemical conditions similar to those of the primary water in a pressurized water reactor. A special corrosion apparatus was built in cooperation with University of Manchester and Škoda JS for the purpose. The initiation is investigated using a Constant Extension Rate Test (CERT) with flat tapered specimens made from Type $316 \mathrm{~L}$ austenitic stainless steel in the vapour environments at $350^{\circ} \mathrm{C}$. Two different surface finishes were used: as-ground and as-polished. Constant extension rate tests with a test rate of $2 \times 10^{-6} \mathrm{~ms}^{-1}$ were performed on 4 specimens - at room temperature and at an elevated temperature of $350^{\circ} \mathrm{C}$ and as a more oxidizing environment was chosen $R=1 / 6$, on the contrary as a more reducing environment was chosen $R=6$, where parameter $R$ represents the ratio between the oxygen partial pressure at the $\mathrm{Ni} / \mathrm{NiO}$ transition and the oxygen partial pressure. Post-test evaluation using SEM was applied.
\end{abstract}

Keywords: Environmentally Assisted Cracking, hydrogenated steam, oxidation

\section{INTRODUCTION}

The 300 series Austenitic Stainless Steels (ASS) are widely used in the nuclear industry due to their reliable long-term performance in high-temperature water. On the other hand, some cases of EnvironmentallyAssisted Cracking (EAC) have occurred in the components of boiled water reactors (BWRs) and recently in pressurized water reactors (PWRs) owing to a hardened layer under the surface induced during the fabrication process [1,2]. The sensitivity to EAC of various surface treatments applied to ASS has been studied in [3]. It was proven that it is connected to the high residual stress as well as to ultrafine-grained/nano-crystalline microstructure layer under the surface several microns thick. The actual stress needed to initiate an EAC crack is likely a sum of the applied and residual stresses.

It has been recognized that EAC initiation of 304L/316 L high resistance SS in water cooling systems operating around $300^{\circ} \mathrm{C}$ is accelerated through increasing the water temperature up to $360^{\circ} \mathrm{C}$ [4]. Accelerated oxidation leads to the formation of an outer $\mathrm{Cr}$-rich oxide and an inner Ni-rich oxide layer as well as grain boundary oxidation. A typical intergranular crack initiates after fracture of the oxide or metal-oxide interface [2,5]. With increasing temperature, higher acceleration of EAC and shorter times to initiation are expected. Under laboratory conditions, one can use temperatures up to $480{ }^{\circ} \mathrm{C}$ with steam vapour. In fact, Economy et al. [6] showed a monotonic dependence of crack growth rate (CGR) and SCC initiation time in both water and steam, suggesting that the SCC initiation mechanism is similar for both environments.

In the paper, the EAC tests have been accelerated by applying three factors: strain rate, steam environment and by increasing the temperature. Dominant acceleration via a constant extension rate test has been employed. Moreover, tapered-shape specimens are used, which allows us to examine a range of stresses and strains simultaneously on one specimen. This type of accelerated EAC testing had been developed in the past [7] and then recently updated within the "Mitigation of Crack Initiation" (MICRIN) project [8]. In the present 
study, the effect of surface treatment on EAC crack initiation has been evaluated for two different surface finishes - as-ground and fine as-polished, which are typically used for laboratory studies.

\section{EXPERIMENT}

\subsection{Material}

This study was performed using 316L ASS produced by Industeel, Alcelor group for the IP EUROTRANS project (Table 1, Table 2). The steel was delivered as $15 \mathrm{~mm}$ thick hot rolled and heat-treated plates. The solution annealing was performed at $1050-1100{ }^{\circ} \mathrm{C}$ in air. Microstructure in as-received state consisted of austenite grains and about $5 \%$ of $\delta$-ferrite stringers oriented in the rolling direction.

Table 1 Chemical composition of the Type 316L ASS (wt.\%)

\begin{tabular}{|c|c|c|c|c|c|c|c|c|c|c|c|c|c|}
\hline Fe & $\mathbf{C r}$ & Mo & $\mathbf{N i}$ & $\mathbf{C}$ & $\mathbf{S i}$ & $\mathbf{M n}$ & $\mathbf{P}$ & $\mathbf{S}$ & $\mathbf{A l}$ & $\mathbf{C u}$ & $\mathbf{T i}$ & $\mathbf{V}$ & $\mathbf{N}$ \\
\hline Bal. & 16.69 & 2.08 & 9.97 & 0.018 & 0.64 & 1.84 & 0.027 & 0.004 & 0.018 & 0.23 & 0.006 & 0.07 & 0.029 \\
\hline
\end{tabular}

Table 2 Mechanical properties of the Type 316L ASS

\begin{tabular}{|c|c|c|c|c|c|c|}
\hline T [ $\left.{ }^{\circ} \mathbf{C}\right]$ & E [GPa] & YS [MPa] & UTS [MPa] & Ag [\%] & A30 [\%] & Z [\%] \\
\hline $\mathbf{2 5}$ & 202 & 251 & 567 & 44 & 60 & 80 \\
\hline $\mathbf{3 5 0}$ & 143 & 168 & 421 & 26 & 38 & 66 \\
\hline
\end{tabular}

\subsection{Surface-treated specimen}

Flat tapered specimens (see Figure 1) were cut using electrical discharge machining (EDM) with the longer side parallel to the rolling direction of the plate. The parallel flat surfaces of the specimens were subjected to different surface finishes: one was manually ground to 500-grit in the direction parallel to the load axis, and the other one was polished using $1 \mu \mathrm{m}$ diamond paste.
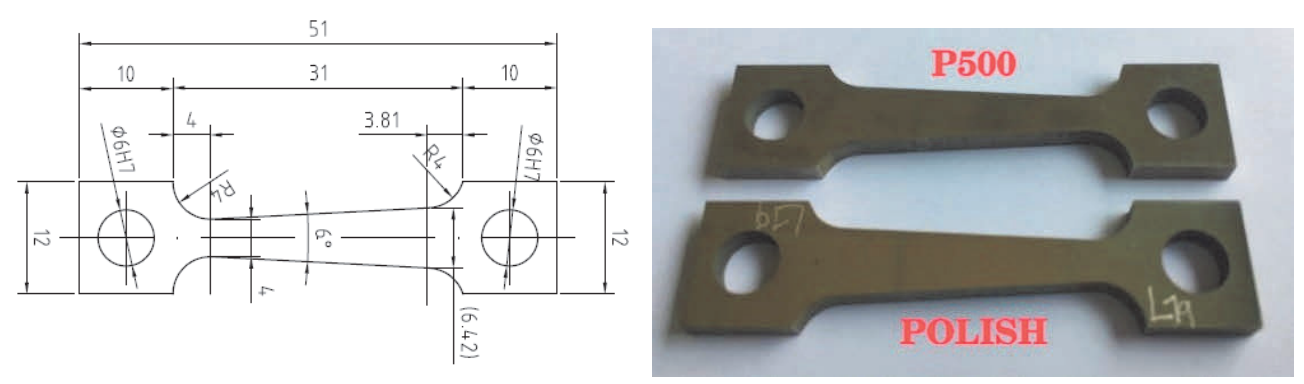

Figure 1 Drawing of used tapered test specimen with polished and ground surface

The arithmetical mean roughness (Ra) of the polished and ground surfaces were $0.005 \mu \mathrm{m}$ and $0.032 \mu \mathrm{m}$ respectively. The HV0.01 micro-hardness measured at about $20 \mu \mathrm{m}$ below the polished and ground surface was $1.94 \mathrm{GPa}(198 \mathrm{HV} 0.01)$, and $2.05 \mathrm{GPa}(209 \mathrm{HV} 0.01)$ respectively.

\subsection{Equipment}

The cell for the low pressure superheated $\mathrm{H}_{2}$-steam environment is currently installed on an electromechanical creep testing machine Kappa SS-CF (see Figure 2) with a load capacity of up to $100 \mathrm{kN}$ and with a speed range from $1 \mu \mathrm{m} / \mathrm{h}$ to $100 \mathrm{~mm} / \mathrm{min}$. The test chamber consists of two main parts - a cover and a vessel. The test chamber vessel primarily serves as a pressure envelope. The test chamber cover is tightened to the vessel using strength bolts and packed with a torus seal. The tested sample is placed in the test chamber cover with 
prismatic reductions. A spring-bellows provides the sealing of the test chamber during linear movement. The filling mixture system consists of a storage tank, a dosing pump, a steam generator, $\mathrm{Ar}+\mathrm{H}_{2}$ gas dosing system and a blender. A special chromatographic pump sucks demi water from the storage tank and doses it into the steam generator. Water evaporates in the steam generator and it passes to the blender as steam. $\mathrm{The} \mathrm{Ar}+\mathrm{H}_{2}$ gas is heated in a parallel pipe and proceeds to the blender where it is mixed with steam. The mixture is mixed in the blender and heated to $200^{\circ} \mathrm{C}$ at which it enters into the test chamber. Using a coiled heat exchanger the mixture can be heated up to $480^{\circ} \mathrm{C}$ and aimed at the tested sample. Since it is a continuous fluid dosing system, the steam with the $\mathrm{Ar}+\mathrm{H}_{2}$ gas will further be drained from the chamber through the drainage system. The drainage system consists of a cooler, a condenser, an air-leak chamber and a waste demi water storage tank. The cooler and condenser form a piping system where the gaseous mixture is cooled down and as the temperature drops below boiling point it liquidizes and proceeds to the air-leak chamber. The air-leak chamber has a free level at a height of approximately 1 metre by which it keeps hydrostatically internal overpressure of approximately 0.1 bar. Once bubbled through the $\mathrm{Ar}+\mathrm{H}_{2}$ gas, the mixture separates from the water. Subsequently, the $\mathrm{Ar}+\mathrm{H}_{2}$ gas flows to the air condition exhaust and water through the overflow to the waste demi water storage tank. This oxidation system was originally developed by Scenini et al. [9] and subsequently used by several laboratories.
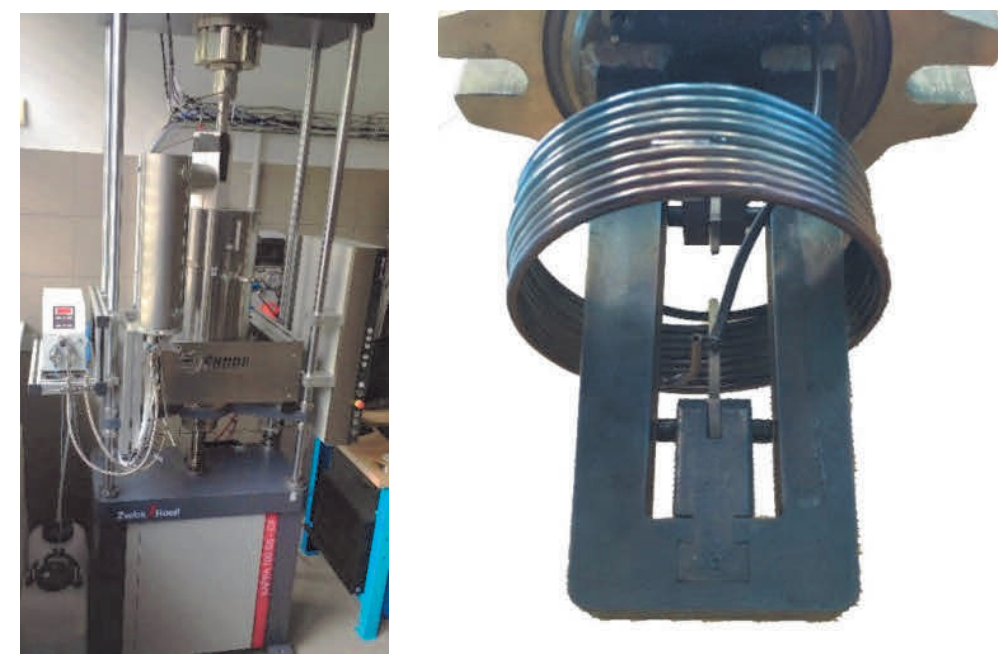

Figure 2 Modification of electromechanical creep testing machine Kappa SS-CF with the corrosion cell for low pressure superheated $\mathrm{H}_{2}$-steam environment and inserted broken specimen after CERT loading

\subsection{Test technique}

The CERT corrosion-mechanical test technique was applied. This technique uses uniaxial tensile testing performed with a very slow constant extension rate. Here, it was a test rate of $2 \times 10^{-6} \mathrm{~ms}^{-1}$, corresponding to maximum strain rates of about $10^{-4} \mathrm{~s}^{-1}$ at the minimum dimensions of the tapered specimen. The tapered parts of specimens were characterized using a TESCAN MIRA3 field emission gun (FEG) SEM.

The oxygen partial pressure was controlled by manipulating the steam to hydrogen ratio $\left(R_{\text {steam } / H 2}\right)$. The relationships for this method are described in [10]. The mixture $6 \% \mathrm{H}_{2}+94 \% \mathrm{Ar}$ was used. To simulate different oxidizing and reducing environments with respect to the $\mathrm{Ni} / \mathrm{NiO}$ transition: the oxygen partial pressure ( $p_{\mathrm{O} 2}$ ) could be varied by changing the $\mathrm{H}_{2}$ partial pressure (e.g. by increasing the $\mathrm{H}_{2}$ flow and hence the $\mathrm{H}_{2}$ partial pressure, the redox potential decreases). The complete thermodynamics of the $\mathrm{H}_{2}$-steam environment can be described using the parameter $R$, which represents the ratio between the oxygen partial pressure at the $\mathrm{Ni} / \mathrm{NiO}$ transition ( $p_{\mathrm{O} 2 \mathrm{Ni}} \mathrm{NiO}$ ) and the oxygen partial pressure $p_{\mathrm{O} 2}$ according to equation (1). For values lower than $1, \mathrm{NiO}$ is stable (oxidizing environment), while for values higher than $1, \mathrm{Ni}$ is stable (reducing environment). 
$R=\frac{p_{\mathrm{O}_{2} \mathrm{Ni} / \mathrm{NiO}}}{p_{\mathrm{O}_{2}}}$

The specimens were tested in a low-pressure $\mathrm{H}_{2}$-steam environment at a temperature of $350{ }^{\circ} \mathrm{C}$ up to rupture. $R=1 / 6$ was chosen as a more oxidizing environment, which corresponds to a water flow rate of $2.22 \mathrm{~mL} / \mathrm{min}$, a gas mixture $\left(6 \% \mathrm{H}_{2}+94 \% \mathrm{Ar}\right)$ of $50 \mathrm{cc} / \mathrm{min}$, a steam-to- $\mathrm{H}_{2}$ ratio of 983 and an oxygen partial pressure of $2.48 \times 10^{-30} \mathrm{~atm}$. On the contrary as a more reducing environment was chosen $R=6$ which corresponds to a water flow rate of $0.37 \mathrm{~mL} / \mathrm{min}$, a gas mixture $\left(6 \% \mathrm{H}_{2}+94 \% \mathrm{Ar}\right)$ of $50 \mathrm{cc} / \mathrm{min}$, a steam-to- $\mathrm{H}_{2}$ ratio of 164 and an oxygen partial pressure of $6.90 \times 10^{-32} \mathrm{~atm}$. Ultrahigh purity water with a conductivity of $0.055 \mu \mathrm{mS} / \mathrm{cm}$ was used. The tapered specimens were exposed to the steam for one day before CERT loading for more reducing environment with $R=6$. The time of exposition was five days before CERT loading for more oxidizing environment with $R=1 / 6$.

\section{RESULTS}

\subsection{CERT curves}

Figure 3 shows the complete results of the tests where each curve corresponds to one sample exposed to a specific environment. The first tensile test with a rate of $2 \times 10^{-6} \mathrm{~ms}^{-1}$ was performed on the same rig at room temperature and $350^{\circ} \mathrm{C}$. To correctly interpret the results, it was necessary to perform tests without a sample at both temperatures. These correction curves have been subtracted from the curves with the specimens because the correction curves represent the resistance of the spring bellows. It can be seen that both correction curves are the same, which means that the temperature does not play any role for the spring bellows, because this part is located outside the chamber.

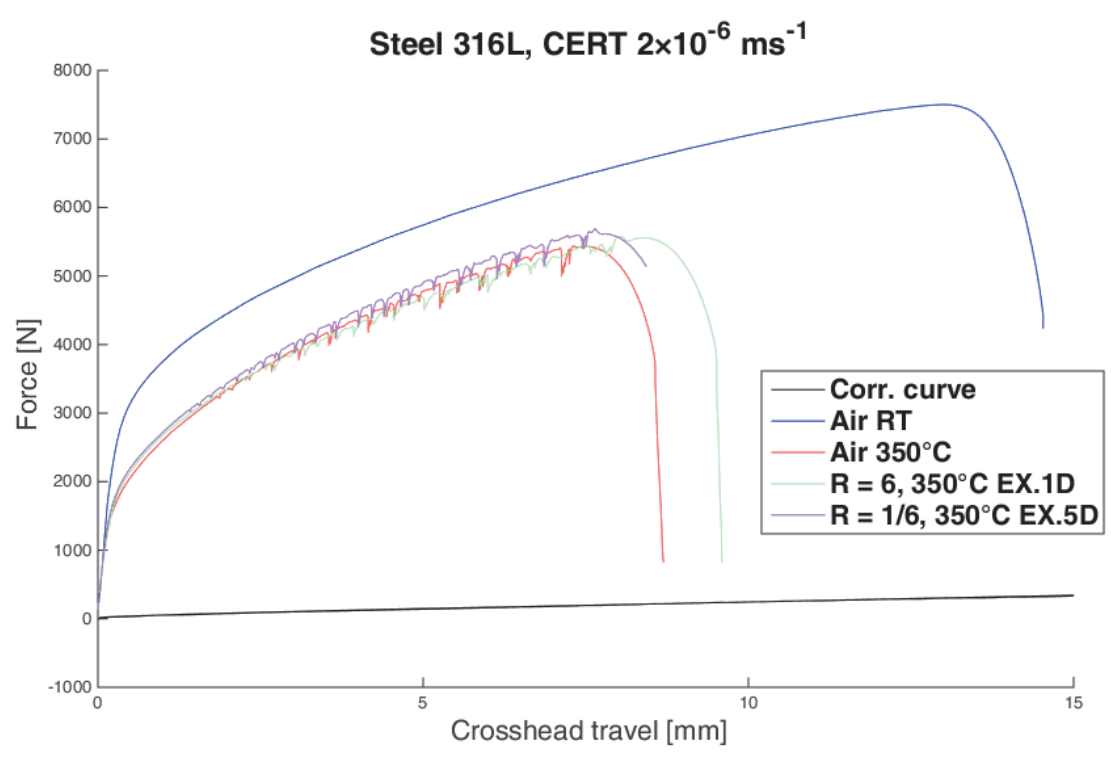

Figure 3 Measured curves of the CERT loading for samples exposed to a specific environment.

The corrected CERT curves of specimens (at $350^{\circ} \mathrm{C}$ ) are plotted in Figure 4. For the tapered specimen tested at room temperature, the maximum stress at the minimum cross section was evaluated to be equal to $612 \mathrm{MPa}$ (note Table $2 \mathrm{UTS}$ value is $567 \mathrm{MPa}$ ). For the specimen at $350^{\circ} \mathrm{C}$ the maximum stress was $458 \mathrm{MPa}$ (Table 2 UTS value is $421 \mathrm{MPa}$ ). Both curves in the $\mathrm{H}_{2}$-steam environments showed longer elongation. The effect is likely higher for the curve in the reducing environment $R=6$, than for the one oxidizing with $R=1 / 6$. At $350^{\circ} \mathrm{C}$ all three curves show oscillations of load, which are typical for dynamic strain ageing. 
Small coupons of pure nickel (99.5 wt.\%) were used in each experiment to control the electrochemical potential with respect to the $\mathrm{Ni} / \mathrm{NiO}$ transition of the high temperature environment. However, it was found that an exposure of one day seems to be insufficient for the material to be affected by the environments.

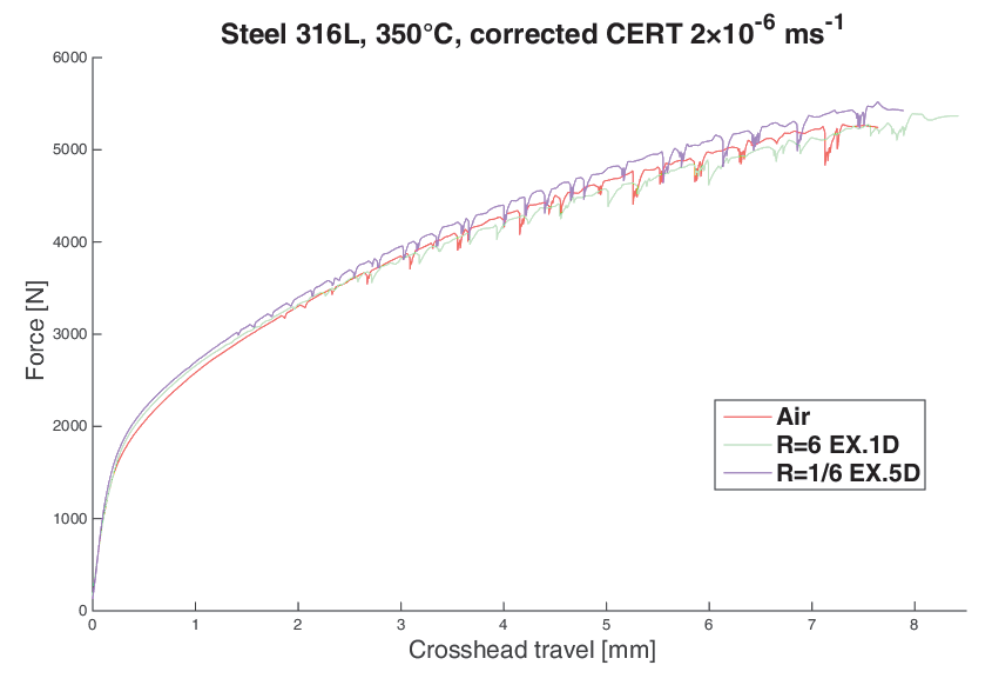

Figure 4 The CERT test curves of the tapered specimens in air and $\mathrm{H}_{2}$-steam at $350{ }^{\circ} \mathrm{C}$ after subtraction of the correction curve

\subsection{Post-test SEM observation}

All specimens failed by ductile fracture with extensive plastic deformation. Post-test evaluation using SEM showed that the flat surfaces were clean, practically without any oxide particles. The polished and ground surfaces behaved similarly. The SEM observation of the fracture shows typical ductile fracture dimples (Figure 5). It proved that a one-day exposure is likely insufficient for the material to be affected by the environments.
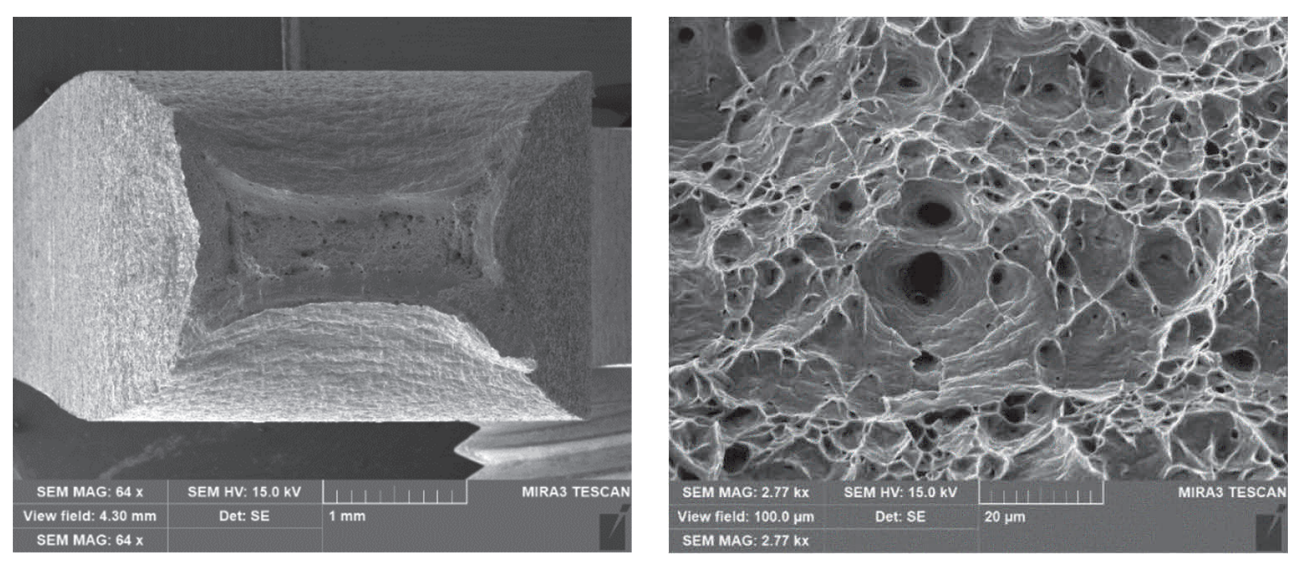

Figure 5 Fracture surface of the tapered specimen after CERT with rate of $2 \times 10^{-6} \mathrm{~ms}^{-1}$ in the $\mathrm{H}_{2}$-steam environment of $R=6$ at $350^{\circ} \mathrm{C}$

\section{CONCLUSION}

A new low pressure superheated $\mathrm{H}_{2}$-steam system was used to perform Constant Extension Rate tests at room temperature and $350{ }^{\circ} \mathrm{C}$. The special corrosion apparatus was built in cooperation with University of Manchester and Škoda JS for the MEACTOS EU project. 
Four flat tapered specimens made from Type 316 L austenitic stainless steel, each with one side polished and the other ground, were investigated. Oxidizing and reducing environments with $R=1 / 6$ and 6 respectively were applied.

The exposure of the $316 \mathrm{~L}$ steel to both $\mathrm{H}_{2}$-steam environments at $350{ }^{\circ} \mathrm{C}$ and loaded with a rate of $2 \times 10^{-6} \mathrm{~ms}^{-1}$ did not lead to initiation of EAC cracking.

\section{ACKNOWLEDGEMENTS}

This work has been undertaken within the SUSEN Project (established in the framework of the European Regional Development Fund (ERDF) in project CZ.1.05/2.1.00/03.0108 and of the European Strategy Forum on Research Infrastructures (ESFRI) in the project CZ.02.1.01/0.0/0.0/15_008/0000293, which is financially supported by the Ministry of Education, Youth and Sports - project LM2015093 Infrastructure SUSEN. The support of Horizon 2020 MEACTOS GA No. 755151 is also acknowledged.

\section{REFERENCES}

[1] SHOJI, Toshio. Progress in the Mechanistic Understanding of BWR SCC and Its Implication to the Prediction of SCC Growth Behavior in Plants. In 11th Int. Conf. Environmental Degradation of Materials in Nuclear Systems. Stevenson: ANS, 2003, pp. 588-599.

[2] COUVANT, T., MOULART, P., LEGRAS, L., BORDES, P., CAPELLE, J., ROUILLON, Y. and BALON, T. PWSCC of austenitic stainless steels of heaters of pressurizers. In 6th Symposium on Materials Investigations and Operating Experience to Light Water NPPs' Safety, Performance and Reliability. Fontevraud: SFEN, 2006, Paper A100-T03.

[3] TURNBULL, A., MINGARD, K., LORD, J. D., ROEBUCK, B., TICE, D.R., MOTTERSHEAD, K.J., FAIRWEATHER, N.D.and BRADBURY, A.K. Sensitivity of stress corrosion cracking of stainless steel to surface machining and grinding procedure. Corrosion Science. 2011. vol. 53, pp. 3398-3415.

[4] COUVANT, T., LEGRAS, L., HERBELIN, A., MUSIENKO, A., ILEVBARE, G., DELAFOSSE, D., CAILLETAUD, G. and HICKLING, J., Development of Understanding of the Interaction between Localized Deformation and SCC of Austenitic Stainless Steels Exposed to Primary PWR Environment. In 14th Int. Conf. on Environmental Degradation of Materials in Nuclear Power Systems. Virginia Beach, 2009, pp. 182-194.

[5] PERSAUD, S. Y., KORINEK, A., HUANG, J., BOTTON, G. A. and NEWMAN, R. C., Internal oxidation of Alloy 600 exposed to hydrogenated steam and the beneficial effects of thermal treatment. Corrosion Science. 2014. vol. 86, pp. 108-122.

[6] ECONOMY, G., JACKO, R. J. and PEMENT, F. W. IGSCC Behavior of Alloy 600 Steam-Generator Tubing in Water or Steam Tests above $360^{\circ} \mathrm{C}$. Corrosion. 1987. vol. 43, no. 12, pp. 727-734.

[7] YU, J., XUE, L J., ZHAO, Z. J., CHI, G. X. and PARKINS, R.N. Determination of Stress Corrosion Crack Initiation Stress and Crack Velocities using Slowly Strained Tapered Specimens. Fatigue Fracture of Engineering Materials and Structures. 1989. vol. 12, pp. 481-493.

[8] BERGER, S., KILIAN, R., RITTER, S., EHRNSTÉN, U., BOSCH, R.-W. and PEROSANZ LOPEZ, F.-J. Mitigation of crack initiation in LWRs (MICRIN+). In Eurocorr 2016. Montpellier: EFC, 2016, Paper No. 65952.

[9] SCENINI, F., NEWMAN, R.C., COTTIS, R.A., JACKO, R.J. Alloy 600 oxidation studies related to PWSCC. In $12^{\text {th }}$ International Symposium on Environmental Degradation of Materials in Nuclear Power System - Water Reactors. Lake Tahoe: Minerals, Metals and Materials Society/AIME, 2005, pp. 891-902.

[10] JANOUŠEK, J., SCENINI, F., VOLPE, L., HOJNÁ, A., TROJAN, T. Instrumentation for SCC testing in low pressure superheated hydrogen steam environments. IOP Conference Series: Materials Science and Engineering. 2018. vol. 461, no. 1, pp. 1-5. 